\title{
Land Registration: Use-case of e-Governance using Blockchain Technology
}

\author{
Karthika Veeramani ${ }^{1}$ and Suresh Jaganathan ${ }^{2 *}$ \\ ${ }^{1}$ Research Scholar, Department of Computer Science and Engineering, \\ Sri Sivasubramaniya Nadar College of Engineering \\ Chennai, TamilNadu, India \\ [e-mail: vkarthikatnj@gmail.com] \\ ${ }^{2}$ Associate Professor, Department of Computer Science and Engineering, \\ Sri Sivasubramaniya Nadar College of Engineering \\ Chennai, TamilNadu, India \\ [e-mail: drjs72@outlook.com] \\ *Corresponding author: Suresh Jaganathan
}

Received December 12, 2019; revised March 31, 2020; revised May 14, 2020; accepted August 2, 2020; published September 30, 2020

\begin{abstract}
e-Governance is a medium to offer various services to citizens through a web portal, that exists in many countries nowadays. The existing e-Governance technology is a vast, centrally managed database and a set of applications that connect to it via web interfaces. Despite the modernisation of services, it remains with the lack of transparency. Thus, the existing infrastructure of e-Governance paves the way for corrupt practises by the bureaucrats. e-Governance needs a powerful underlying technology which doesn't provide any way to allow tampering of the record and which in turn eliminates corruption. In this paper, we took land registration as a use-case for building e-Governance by keeping Blockchain as an underlying technology, to put off the corrupt practices and to bring transparency. Once transactions in land registration added to the Blockchain, it is immutable as it is cryptographically secured. Besides, the blockchain technology is secured as the ledger is distributed over the network. If a hacker wants to modify the ledger, he needs to hack every node in the blockchain network. Hyperledger Fabric, a permissioned Blockchain adopted for implementation and Hyperledger Caliper for performance analysis with these evaluation metrics such as throughput, latency and execution time.
\end{abstract}

Keywords: Blockchain Technology, Distributed Ledger, e-Governance, Land Registration 


\section{Introduction}

E-Governance modifies the functioning of the government using Information and Communications Technology (ICT). It transforms the effectiveness, efficiency, accountability, and transparency of information exchanged and transaction between governments and Government Agencies, citizens and businesses [1]. For example, instead of going to the railway tickets reservation centre to book tickets, citizens can book online; thus, saving time.

According to the World Bank in 2015, "e-Government refers to the use of information technologies (such as wide area networks, the internet, and mobile computing) by the government that can transform relations with citizens, businesses, and other arms of government" [2]. But, according to UNDP 2016, "e-Governance involves a public investment in information and communication technologies (ICTs) to strengthen governance processes. Access to and use of ICTs can provide new and innovative communication channels that empower people and give voice to those who previously had none while allowing them to interact via the internet". As a result, e-Governance is a larger term than e-Government since the former employs the Governance of organisations, while the latter deals strictly about the government.

e-Governance also aims to equip people by giving them access to information that makes the entire administrative process friendly and is essential for a developing country like India. A practical example of successful implementation of e-Governance is an e-Sevai project developed by the state of Tamilnadu, India offering 21 services in revenue department currently.

The very primary objective of e-Governance is to provide every piece of government information to the citizens [3]. The other goals include developing an empowered society, building better interaction between government and citizen, encouraging citizen engagement in the governing process, bringing transparency and thereby making the government accountable to the citizens. It will reduce the response time of the government to people's queries and problems which adds an advantage of reducing the cost of Governance.

e-Governance was introduced to deliver essential services to citizens, yet it has not achieved its full potential. Some of the barriers in India include

- Overall internet users in India are 560 million only (as of January 2019).

- Most of the departments are still preferring analogue or paperwork; thus, the slow rate of modernisation has limited the use of e-Governance.

- Susceptible to cyber-attacks.

- Lack of interconnectivity among government departments.

- Lack of proper information about e-Governance to people.

Indian Government has taken many initiatives to improve the usage of e-Governance like Digital India scheme [4], BharatNet scheme for optical fibre connectivity in Gram Panchayats. These schemes improved e-Governance to some extent, suggestions to improve, listed below:

- Training the officials those with the lack of computer/internet literacy.

- Familiarize people about e-Governance.

- Regulate the internet for safe usage.

- Increase internet penetration with technology, increased speed and reduced traffic. 


\subsection{Problem Definition}

The existing infrastructure of e-Governance is a centrally managed database and provides a list of services that connect to it via web interfaces [5]. Despite the government's modernisation of services to citizens, e-governance remains with the corruption by the bureaucrats due to lack of transparency. The openness of e-Governance is questionable as the governments themselves manage it. So, the data can be appended or discarded from the public eye by the officials. There is a need to increase the transparency level of the government to trust it by the citizens. Weak Governance led to corruption, while good Governance provides transparency. So, the e-Governance needs a powerful underlying technology which doesn't offer any way to allow tampering of the record and which in turn eliminates corruption.

\subsection{Our Solution}

Blockchain technology (BT) is one such technology that can solve the problem of lack of transparency in the e-Government [6][7]. Moreover, one cannot merely append or discard the data without the knowledge of concerned authority or from the public. Though it is possible to change the data, it will be stored in the distributed ledger so that no one would escape from the consequences of it.

One of the most emerging technology is Blockchain that can alleviate any loophole in e-Governance to tamper the record by the officials and citizens. Blockchain technology can record every activity of services provided by e-Governance through the distributed ledger, and it can reduce the risk associated with a lack of transparency, data tampering while improving trust and visibility. Once the block containing the data inserted into the Blockchain, modification is not possible. Data immutability is the primary feature of Blockchain technology. It adds benefit to the existing e-Governance system. For anyone who wants to change past transactions for which he has to compromise all the others in the network to reach consensus, it will be an extremely challenging task. Thus, Blockchain becomes a perfect technology to record transactions due to its economic benefit and high security.

The rest of the paper organised as Section 2 discuss the works related to the use of BT for e-Governance. Section 3 explores how e-Governance improved when adopting Blockchain Technology. This section details the process using a use-case - land registration. Section 4 presents the outcomes with evaluation metrics. Section 5 discusses the strengths of the proposed work and compares it to a similar system, and the paper concludes in Section 6 .

\section{Literature Survey}

The United Nations releases the E-government survey or e-governance development index (EGDI) [8] biennial based on three dimensions: online service index (OSI), telecommunication infrastructure index (TII), and human capital index (HCI). The last survey launched on July 19, 2018, with the theme "Gearing E-Government to Support Transformation towards sustainable and resilient societies". Out of 193 countries, India takes 96th position in 2018 as it jumped 11 places from 107th position in 2016. The jump shows how digital technologies and innovations are impacting the public sector and changing people's everyday lives [9].

The survey also talks about India's Aadhar program that serves as the basis for the citizen to interact with the Government at various levels. It also indicates an anti-corruption initiative "I Paid a Bribe" taken by Janaagraha, an India based non-governmental organisation, focusses on Retail industry. Janaagraha empowers citizen, governments and advocacy organisations to 
tackle local corruption both within India and increasingly throughout the world. Though India earns a place among 100 countries in UN e-Government index, it has the following key challenges to improve its position.

- ICT infrastructure in rural areas should be improved.

- Low Income-per-capita causes higher marginal cost by the dollar spent.

- Need to provide many more online access points to all citizen.

- For e-Government development, the necessary resources should be identified and made readily available.

e-Governance in India emerged from computerisation to service orientation, citizen focus and transparency of government departments. The National e-Governance Plan (NeGP) intends to bring public services closer to citizens. Its vision states, "To make all government services accessible to the common man in his locality, through common service delivery outlets, and to ensure the efficiency, transparency and reliability of such services at an affordable cost to meet the basic needs of the common man." [10]. The Networked Readiness Index(NRI) measures countries' progress in creating basic requirements for a shift towards a digitised economy and society. World Economic Forum (WEF) releases this index and India takes 91st position out of 139 countries in 2016 with score 3.8 out of 7. This low score indicates that India needs growth towards digitalisation.

In paper [11] it discusses some significant obstacles in implementing e-Governance in India. They categorised the challenges as Environmental, Social, Economic and Technical Challenges. It questions about the trust in technologies used by the government for e-Governance. The underlying technology of e-Governance should make a balance between preventing fraudulent transactions and extensive checking of the stakeholders involved, such as citizen, government officials. The introduction of e-Governance applications has made right separation from long queues, delaying tendency of officials, procedural complexities, direct and indirect demands for a bribe [12]. The Government is responsible for managing and holding official records of citizens. Blockchain enables the Government to change the way it records the transaction at the local or state level [13]. Blockchain offers accountability, safety, and automation in handling public records. It could potentially prevent corruption and make government services more productive. Example of some services in e-Governance includes identification, taxes, voting, etc. [14][15].

The China government has undertaken a project named "The Comprehensive Experimental Area of Big Data in Guangdong Province" to make use of Blockchain technology in its e-Government to achieve improvements in quality, quantity, transparency, and accessibility of government services. The paper also discusses the challenges in applying the Blockchain technology in Chinese e-Government and suggests some solutions. It includes establishing standards, deploying robust management systems and ensuring security [16].

Estonia became the first country to open its digital borders to allow anyone, anywhere in the world to become e-resident in December 2014. The primary objective of issuing e-ID to e-Resident is to enable commercial activities with public and private sectors without a physical presence in Estonia. For example, if e-Resident wishes to open a bank account in Estonia, he can do it without the need to travel to Estonia. Estonian government partnering with Bitnation offers this digital identity service to e-Residents, based on robust technology Blockchain. The distributed public ledger utilised to create and manage the digital identity of e-Residents. It could potentially improve the way digital identity is controlled and authenticated. Moreover, the information stored in the ledger are secured cryptographically and are decentralised [17]. 
The use of Blockchain technology in the smart city enables devices to have secure data communication in a distributed environment. It provides some unique features such as reliability, fault tolerance, and scalability [18][19]. Tourism in the Republic of Moldova makes use of Blockchain and Bitcoin as a means to lift the country out of poverty. The travel companies could adopt Blockchain technology to improve accounting process, that involves complex ledgers to track and settle payments in multiple countries and currencies [20].

The paper [21] discusses some relationships exist between blockchain ad bureaucracy. The first association between them is executing some predefined rules as rules are the law for them. They serve as information processing and trusted systems for society. With all these similarities, it is possible to replace bureaucracy with blockchain technology.

Many governments in the world carried out various projects driven by Blockchain technology. Table 1 summarises the blockchain projects managed by multiple governments around the globe. Notably, the countries like Ghana, Georgia and Honduras proposed the idea of blockchain-based land registry. In Ghana, a US-based organisation Bitland is working on its implementation and is still in progress. Bitfury, a blockchain technology company, is developing the land registry project for Georgia and is in progress. Though Honduras launched its land registry project in 2015, the significant difficulty faced in effective implementation of their project is its political instability. The real-time implementation of various schemes of adopting Blockchain in e-Governance is in question as there is no published evidence. Even some companies involved in blockchain development had proof of concept, they hold it confidential.

Table 1. Examples of government-led blockchain projects

\begin{tabular}{|c|c|c|}
\hline Country & Project & Status \\
\hline \multirow[b]{2}{*}{ Australia } & $\begin{array}{l}\text { Australian senators began parliamentary friends of a } \\
\text { blockchain group.[22] }\end{array}$ & $\begin{array}{l}\text { Published on August 8, } \\
2017\end{array}$ \\
\hline & $\begin{array}{l}\text { Blockchain-based Australian Securities Exchange } \\
\text { (ASX)[23] }\end{array}$ & $\begin{array}{l}\text { Started in } 2015 \text { and } \\
\text { expected to complete it } \\
\text { by } 2021 .\end{array}$ \\
\hline \multirow{3}{*}{ China } & Social security funds [24] & \multirow{2}{*}{ Published in 2016} \\
\hline & Blockchain for Mortgage valuations [25] & \\
\hline & Blockchain oriented smart city[26] & $\begin{array}{l}\text { Published in November } \\
2019\end{array}$ \\
\hline Dubai & Blockchain-based smart Dubai [27] & Published in 2016 \\
\hline \multirow{3}{*}{ Estonia } & Electronic identification system [28] & Inprogress \\
\hline & $\begin{array}{l}\text { e-Health records [29], e-Ambulance [30], } \\
\text { e-Prescription [31] }\end{array}$ & Inprogress \\
\hline & e-Residency [17] & Since 2015 \\
\hline France & Blockchain platform for unlisted securities trade [32] & $\begin{array}{l}\text { Published in December } \\
2017\end{array}$ \\
\hline Ghana & Blockchain-based land registry [33] & Inprogress \\
\hline Georgia & Blockchain-based land registry [34] & Inprogress \\
\hline Honduras & Blockchain-based land registry [35] & Launched in 2015 \\
\hline Kazakhstan & Cryptocurrency based payment systems [36] & $\begin{array}{l}\text { Published on July 17, } \\
2017\end{array}$ \\
\hline Russia & $\begin{array}{l}\text { Blockchain-based patient's medical history exchange } \\
\text { [37] }\end{array}$ & $\begin{array}{l}\text { Published on August } \\
10,2017\end{array}$ \\
\hline Singapore & Cross-border interbank payments [38] & Started in 2016 \\
\hline Sweden & Smart contracts for land registry [39] & Examined in early 2017 \\
\hline
\end{tabular}




\begin{tabular}{|l|l|l|}
\hline Switzerland & Blockchain-based digital identity [40] & Published in 2017 \\
\hline $\begin{array}{l}\text { United } \\
\text { Kingdom } \\
\text { (UK) }\end{array}$ & Blockchain-based welfare payment system [41] & $\begin{array}{l}\text { Published in July 2016 } \\
\text { and Proof of concept is } \\
\text { successful }\end{array}$ \\
\hline $\begin{array}{l}\text { United } \\
\text { States(US) }\end{array}$ & Blockchain-based patient health record exchange [42] & Published in 2018 \\
\hline
\end{tabular}

\section{Blockchain Framework for Land Registration}

The Blockchain is an open, decentralised/distributed public ledger that stores transactions between nodes in the network without the need for an intermediatory. In other words, Blockchain is a series of blocks with header and body. It records every transaction or list of transactions within a particular time on the network as a block. The block header provides timestamp, previous block hash pointer, etc. and the block body has a list of transactions. Blockchain eliminates the need for any central authority and operates on a peer-to-peer network where every node maintains a copy of the Blockchain. The previous block hash pointer provides integrity to the transactions, making it difficult for anyone to mutate the blocks in the Blockchain, thereby data in the blocks cannot be modified or deleted. The key characteristics of Blockchain technology are immutability, transparency, availability, privacy and consistency.

Fig. 1 shows the current land registration process, which is prevalent with corruption. Some other challenges in the current system include untrustworthy, inefficiencies, etc. As per the Transparency International report, $20 \%$ of land registration service has done after paying the bribe to some officials. Even, for simply verifying the ownership of land, some officials demand bribe from the citizen. Government officials can leverage their power to modify the land information without the risk of identification. With the use of Blockchain technology, it is possible to overcome these challenges in the current Land registration system. Blockchain technology could potentially improve the transparency of land records and transfer, as it maintains a permanent record of transactions.

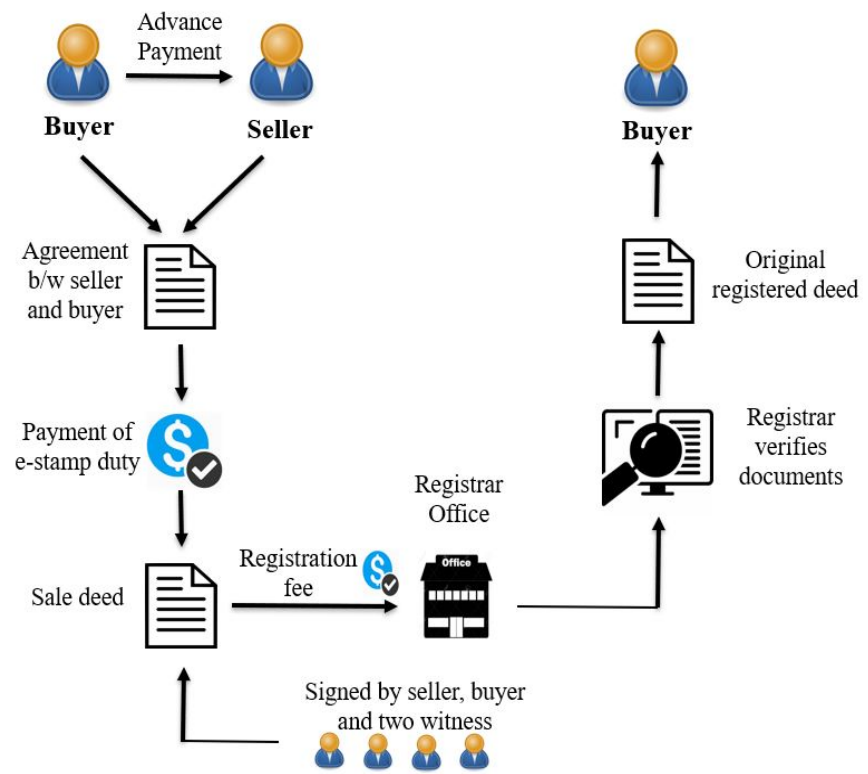

Fig. 1. The current process in Land Registration 
Fig. 2 shows the proposed blockchain framework for the land registration process. The general structure of a block in Blockchain consists of header and body, in which the block header has block ID, previous block hash, current block hash, and Merkle tree. Merkle tree has a hash of data in every leaf node and a hash of its child in every non-leaf node.

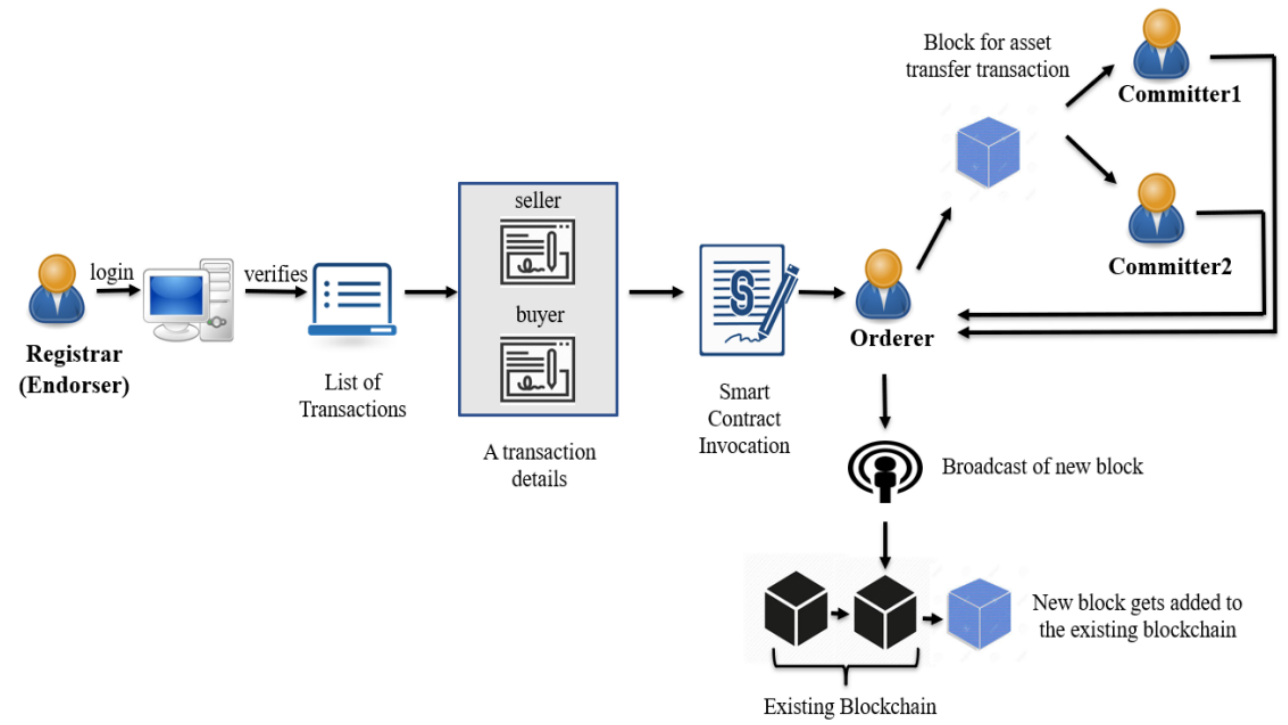

Fig. 2. Land Registration using Blockchain technology

Fig. 3 depicts the structure of blocks in Blockchain for land registration. With all completed transactions at the end of the day, the block gets added to the chain. The sample blockchain for land registration consists of 4 blocks. The block with ID 100 has one transaction, i.e. only one transaction done on that day. Similarly, the blocks with ID 101, 102 and 103 has four, three and one transaction respectively. Fig. 4 shows an example of a Merkle tree consisting of 4 blocks.

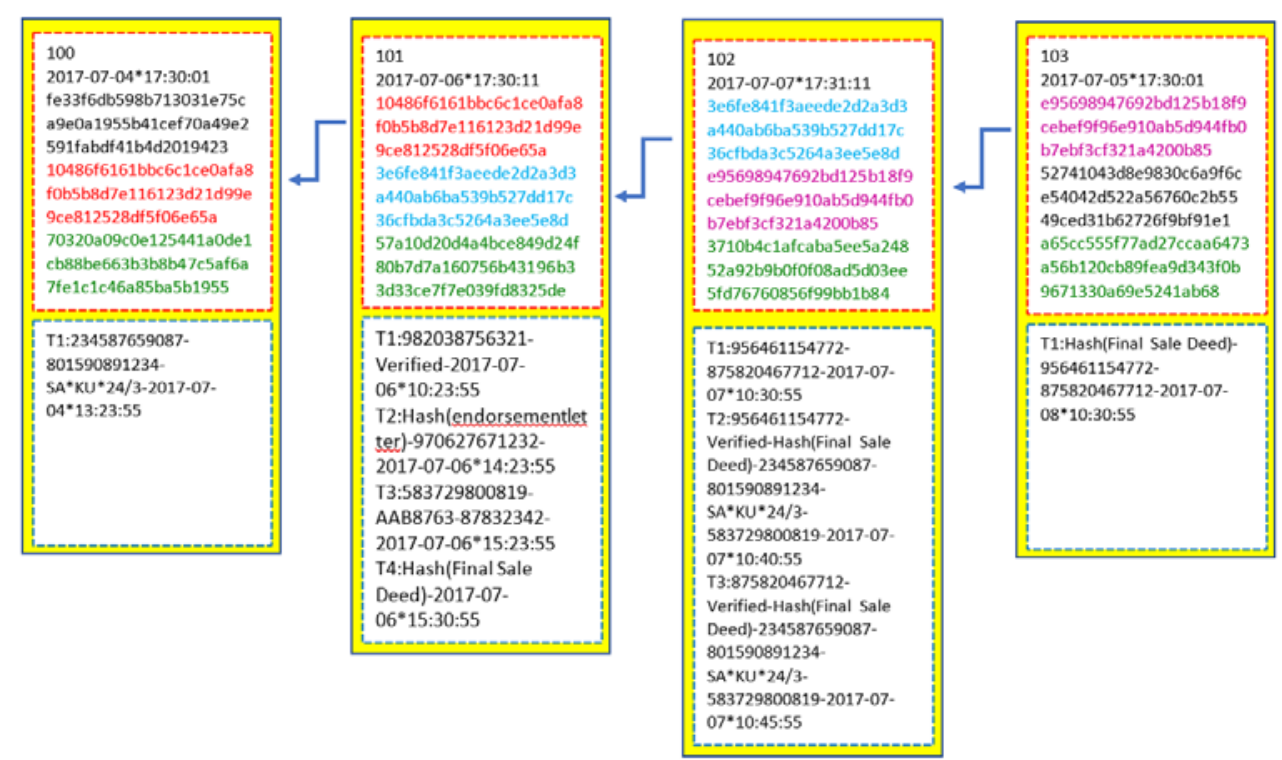

Fig. 3. Structure of blocks in Blockchain for Land Registration 


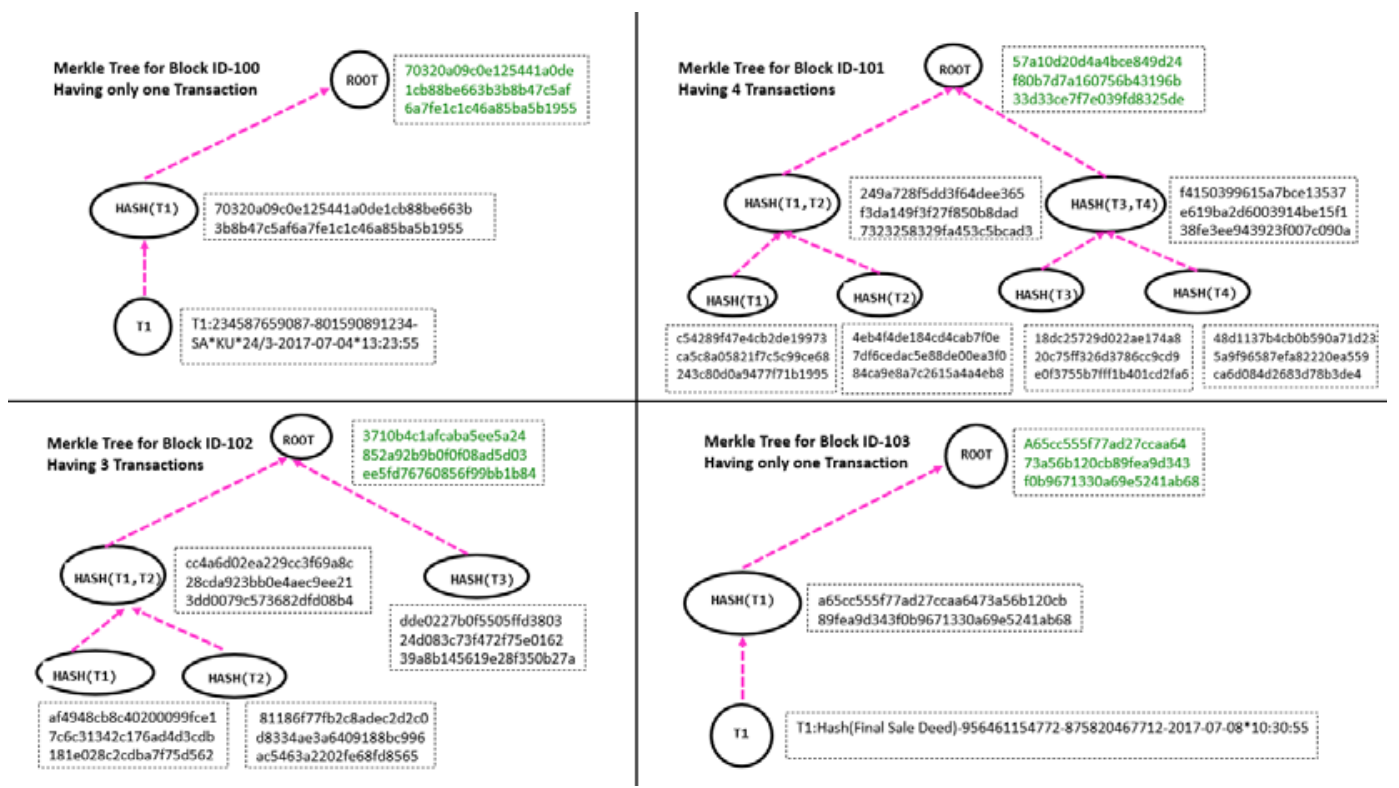

Fig. 4. Merkle Tree

Once the land is ready for sale, the buyer and seller interact themselves and comes to an agreement to transfer of land and follows the below steps:

1. The seller and buyer register for land transfer through the land registration site.

2. Once the seller and buyer accept for land transfer, the smart contract in Blockchain gets invoked and begins to log important activity in the ledger.

3. The draft version of the sale deed produced in pdf format. The pdf along with details such as seller aadhaar number, buyer aadhaar number, asset ID, timestamp, and TIN, GST(in case of buyer applies for bank loan) inserted as a transaction in the ledger[Transaction1].

4. The registrar goes through the draft sale deed online and verifies the details such as whether the land belongs to his/her official limit, Aadhaar details of both seller and buyer, land details, stamp duty and registration fee.

5. The registrar notifies the buyer and seller regarding the acceptance with the final draft sale deed to proceed further. The details such as registrar aadhaar, verification status, and timestamp, inserted as a transaction in the ledger[Transaction2].

6. The authorised document writer should endorse the final draft sale deed. The buyer uploads the endorsement letter in the land registration site. The endorsement letter, document writer aadhaar number and timestamp inserted as a transaction in the ledger[Transaction3].

7. The buyer initiates the e-Stamp payment and registration fee for land transfer. Also, the buyer made a final payment to the seller. The ledger stores e-Stamp payment ID, registration ID and final payment transaction ID along with timestamp as a transaction[Transaction4].

8. The land registration system generates the final sale deed. It is timestamped and stored as a transaction in ledger[Transaction5].

9. The final sale deed sent to two registrars(randomly chosen) for approval. The registrars aadhaar number, timestamp stored as a transaction in ledger[Transaction6].

10. Each registrar verifies the final sale deed and details such as a seller, buyer, land, e-Stamp payment, registration fee, etc. If the registrar approves the land transfer, the 
ledger stores all details as transaction separately for each registrar[transaction-7.1 for registrar A and transaction-7.2 for registrar B].

11. The approved copy of sale deed sent to the buyer/bank (in case of a loan) and transaction stored in the ledger[Transaction8].

State machine (SM) representation is a model that groups the process in a system. To check whether the system performs well, do evaluation. State Machines rely on mathematical equations, to express the logic of a system. In our work, we used this kind of representation for proving our system performs well and proves the system implemented is secure (refer to Table 3, and the terms used explained in Table 2). In our system, we have eight different states, and each state depends on each other's if one state fails then the entire system collapses. Our business logic written as smart contract and implemented in Hyperledger Fabric tool follows the representation and hence the system is secured.

Table 2. Key Terms

\begin{tabular}{|c|l||c|l|}
\hline Term & \multicolumn{1}{|c||}{ Explanation } & Term & \multicolumn{1}{c|}{ Explanation } \\
\hline$S$ & state & Asset $_{I D}$ & unique identifier of the asset(land) \\
\hline$S^{\prime}$ & state transition & $S D_{\text {draft }}$ & Draft version of the sale deed \\
\hline$t$ & transaction & $S D_{\text {final }}$ & Final version of the sale deed \\
\hline$O_{t}$ & operation on transaction t & $A S D_{\text {final }}$ & Approved final sale deed \\
\hline$R_{t}$ & the response of transaction & Aadhar $_{R e}$ & Aadhar number of registrar \\
\hline$S e$ & Seller & eStamp $_{I D}$ & eStamp duty transaction ID \\
\hline$B u$ & Buyer & Registration $_{I D}$ & Registration fee ID \\
\hline$T S$ & Timestamp & Status $_{R e}$ & $\begin{array}{l}\text { Registrar's approval status of land } \\
\text { registration to proceed further }\end{array}$ \\
\hline$K e y_{p u}$ & Public key & Payment $_{I D}$ & $\begin{array}{l}\text { Final payment transaction ID from } \\
\text { buyer to seller }\end{array}$ \\
\hline$K e y_{p r}$ & Private key & Endorsement $_{D W}$ & $\begin{array}{l}\text { Endorsement of draft sale deed by } \\
\text { document writer }\end{array}$ \\
\hline$D W$ & Document Writer & Approval $_{R e_{A}}$ & $\begin{array}{l}\text { The approval status of land registration } \\
\text { by Registrar A }\end{array}$ \\
\hline$R e_{A}$ & Registrar A & Approval $_{R e_{B}}$ & $\begin{array}{l}\text { The approval status of land registration } \\
\text { by Registrar B }\end{array}$ \\
\hline$R e_{B}$ & Registrar B & \\
\hline
\end{tabular}

Table 3. Details of transaction log in the land registration process using Blockchain Technology

\begin{tabular}{|c|c|c|c|}
\hline $\begin{array}{l}\text { Action } \\
\text { Name }\end{array}$ & Details & Transaction log & $\begin{array}{l}\text { Transaction } \\
\text { No. }\end{array}$ \\
\hline \multirow{2}{*}{$\begin{array}{l}\text { Generation } \\
\text { of Draft Sale } \\
\text { Deed }\end{array}$} & $\begin{array}{l}\text { Step } 3 \text { - Draft version of sale deed } \\
\text { generated - PDF file - consists of seller } \\
\text { and buyer Aadhaar details, asset ID, } \\
\text { timestamp if loan applied then TIN and } \\
\text { GST of Bank included }\end{array}$ & $\begin{array}{l}\text { Seller Aadhaar details } \\
\text { Buyer Aadhaar details } \\
\text { Asset ID } \\
\text { Timestamp }\end{array}$ & 1 \\
\hline & \multicolumn{3}{|c|}{$\begin{array}{l}S_{t 1} \leftarrow\left[\text { Aadhar }_{S e, B u}, \text { Asset }_{I D}, T S\right], O_{t 1} \leftarrow[\text { Generation of draft sale deed }] \\
S_{t 1}^{\prime} \leftarrow\left[\text { Aadhar }_{S e, B u}, \text { Asset }_{I D}, T S_{t 1}, S D_{\text {draft }}\right], R_{t 1} \leftarrow E_{\text {Key }_{p u}}\left(S_{t 1}^{\prime}\right)\end{array}$} \\
\hline
\end{tabular}




\begin{tabular}{|c|c|c|c|}
\hline \multirow[b]{2}{*}{$\begin{array}{l}\text { Checking of } \\
\text { generated } \\
\text { Draft Sale } \\
\text { Deed }\end{array}$} & $\begin{array}{l}\text { Step } 5 \text { - Registrar checks the draft sale } \\
\text { deed and communicates the status to } \\
\text { seller and buyer to proceed further }\end{array}$ & $\begin{array}{l}\text { Registrar Aadhaar details } \\
\text { Verification Status } \\
\text { Timestamp }\end{array}$ & 2 \\
\hline & \multicolumn{3}{|c|}{ 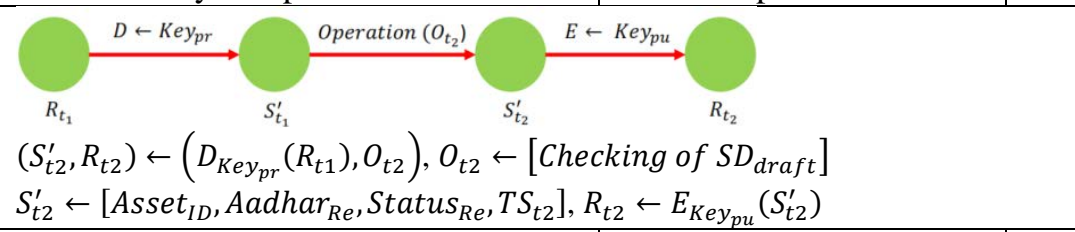 } \\
\hline \multirow[b]{2}{*}{ Endorsement } & $\begin{array}{l}\text { Step } 6 \text { - Authorised document writer } \\
\text { endorses the final draft sale deed }\end{array}$ & $\begin{array}{l}\text { Document writer Aadhaar } \\
\text { details } \\
\text { Copy of endorsement } \\
\text { letter and Timestamp }\end{array}$ & 3 \\
\hline & 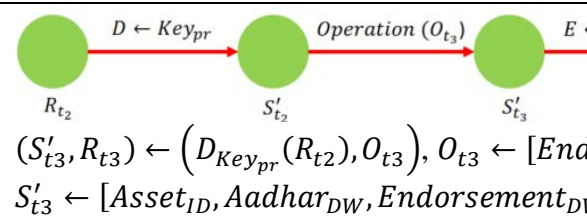 & $\begin{array}{l}R_{t_{3}} \\
\text { rsement }] \\
\left.T S_{t 3}\right], R_{t 3} \leftarrow E_{\text {Key }}\left(S_{t 3}^{\prime}\right)\end{array}$ & \\
\hline \multirow{2}{*}{$\begin{array}{l}\text { Payment of } \\
\text { Stamp duty }\end{array}$} & $\begin{array}{l}\text { Step } 7 \text { - Buyer initiates the payment of } \\
\text { stamp duty - eStamp }\end{array}$ & $\begin{array}{l}\text { eStamp payment ID } \\
\text { Registration ID } \\
\text { Final payment ID } \\
\text { Timestamp }\end{array}$ & 4 \\
\hline & $\begin{array}{l}\bigcup_{R_{t_{3}}}^{D \leftarrow K e y_{p r}} \longrightarrow \bigcirc_{S_{t_{3}}^{\prime}}^{\text {operation }\left(o_{t_{4}}\right)} \bigcirc_{S_{t_{4}}^{\prime}}^{E} \\
\left(S_{t 4}^{\prime}, R_{t 4}\right) \leftarrow\left(D_{\text {Key }}\left(R_{t 3}\right), O_{t 4}\right), o_{t 4} \leftarrow[\text { Pay } \\
S_{t 4}^{\prime} \leftarrow\left[\text { Asset }_{I D}, \text { eStamp }_{I D}, \text { Registration }\right. \\
\text { ID }\end{array}$ & ayment $\left._{I D}, T S_{t 4}\right], R_{t 4} \leftarrow E_{K e y_{p}}$ & \\
\hline \multirow[b]{2}{*}{$\begin{array}{l}\text { Final Sale } \\
\text { Deed }\end{array}$} & $\begin{array}{l}\text { Step } 8 \text { - Land Registration office } \\
\text { generates the final version of Sale Deed } \\
\text { - contains Endorsement Letter + Sale } \\
\text { Deed + eStamp payment details }\end{array}$ & $\begin{array}{l}\text { Copy of Final Sale Deed } \\
\text { Timestamp }\end{array}$ & 5 \\
\hline & $\begin{array}{c}R_{t_{4}} \\
\left(S_{t 5}^{\prime}, R_{t 5}\right) \leftarrow\left(D_{\text {Key }_{p r}}^{t_{4}}\left(R_{t 4}\right), O_{t 5}\right), O_{t 5} \leftarrow[\text { Fin } \\
S_{t 5}^{\prime} \leftarrow\left[\text { Asset }_{I D}^{\prime}, S D_{\text {final }}, T S_{t 5}\right], R_{t 5} \leftarrow E_{\text {Key }}\end{array}$ & $\begin{array}{l}D e e d] \\
\left.S_{t 5}^{\prime}\right)\end{array}$ & \\
\hline \multirow{2}{*}{$\begin{array}{l}\text { Initiation of } \\
\text { Verification }\end{array}$} & $\begin{array}{l}\text { Step } 9 \text { - Final Sale deed is sent randomly } \\
\text { to two Registrars for approval. }\end{array}$ & $\begin{array}{l}\text { Registrar-A Aadhaar } \\
\text { details } \\
\text { Registrar-B Aadhaar } \\
\text { details } \\
\text { Timestamp } \\
\end{array}$ & 6 \\
\hline & 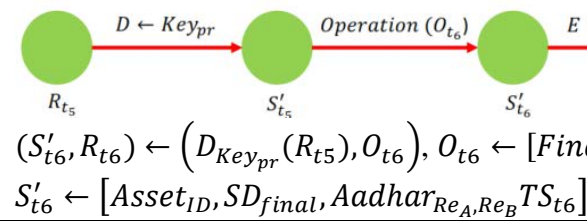 & $\begin{array}{l}\text { Deed }{ }^{{ }^{t_{t_{6}}}} \\
R_{t 6} \leftarrow E_{\text {Key }}\left(S_{t 6}^{\prime}\right)\end{array}$ & \\
\hline \multirow{2}{*}{$\begin{array}{l}\text { Verification } \\
\text { Process }\end{array}$} & \multirow{2}{*}{$\begin{array}{l}\text { Step } 10 \text { - Registrars check the sale deed } \\
\text { for its legitimacy }\end{array}$} & $\begin{array}{l}\text { Registrar-A Aadhaar } \\
\text { details, Approval Status } \\
\text { and Timestamp }\end{array}$ & 7.1 \\
\hline & & $\begin{array}{l}\text { Registrar-B Aadhaar } \\
\text { details, Approval Status }\end{array}$ & 7.2 \\
\hline
\end{tabular}




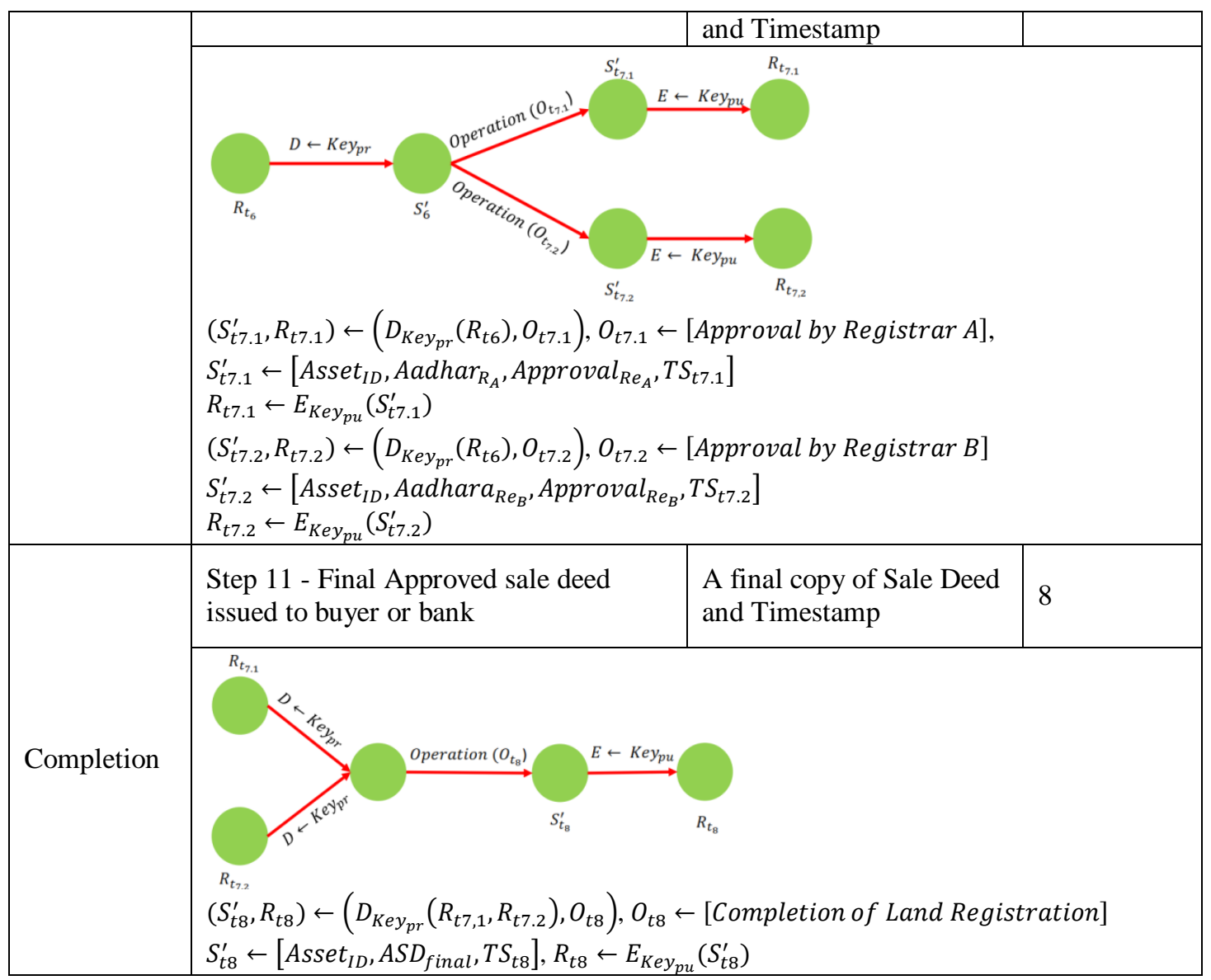

Fig. 5 shows a sample representation of blockchain-based land registration. The organisation setup consists of a peer node at each district registration office and orderer node for creating blocks and ordering the transactions in it. The land registration network has five components

- Certificate Authority cerrificate Authority is a peer who issues and manages certificate to other peers in the organisation.

- Client (Seller/Buyer) is the citizen who initiates the land registration process via a land registration portal.

- Endorser Registrar-A Registrar-B is the registrar who verifies and approves the land registration.

- Orderer transactions done in a day and broadcast it across the peers in the network.

- Validator Registrar-A Registrar-B is a peer validates the transactions in the block and add it to the ledger. 


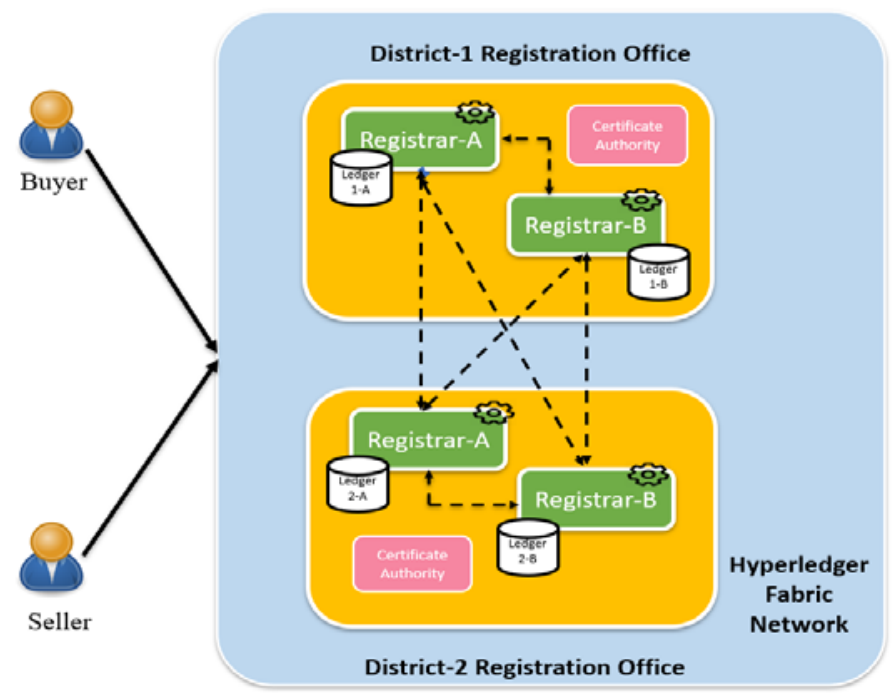

Fig. 5. Blockchain-based Land Registration

Endorsement policy defines which peers in the network approve the transaction and as a result transaction gets added to the ledger. The existing land registration takes longer time in service delivery, and it has no rating mechanism for the government officials involved. The proposed Blockchain-based framework for land registration has a reputation system for government officials for timely delivery of approving or rejecting the land registration process. If the government official made some malpractice in approving the land registration, it is easy to trace back the activity where it went wrong and can identify the officials.

The network for the land registration using blockchain technology consists of district registration offices and Orderer. Each district registration office has certificate authority node, two registrars' nodes, namely Registrar A and Registrar B. The registrar node maintains an individual ledger where it stores a chain of blocks with a list of transactions. The job of the Orderer is to order the transactions and create a new block of these transactions. It also broadcasts the block to all peers for confirmation. The Orderer is the main component in the network as it acts as a hub for distributing blocks to all peers. If the Orderer has a node, there will be a single point of failure. So, the Orderer has n number of nodes for fault tolerance. Moreover, a node in Orderer interconnected among other nodes in it to reach distributed consensus in creating a new block of ordered transactions.

Algorithm 1[seller], 2 [buyer] and 3 [transfer] describe the sequence of steps to be followed by seller and buyer in transferring the asset.

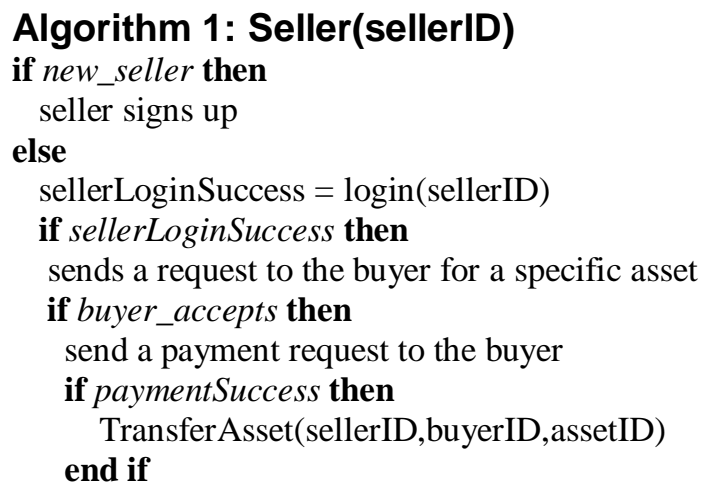

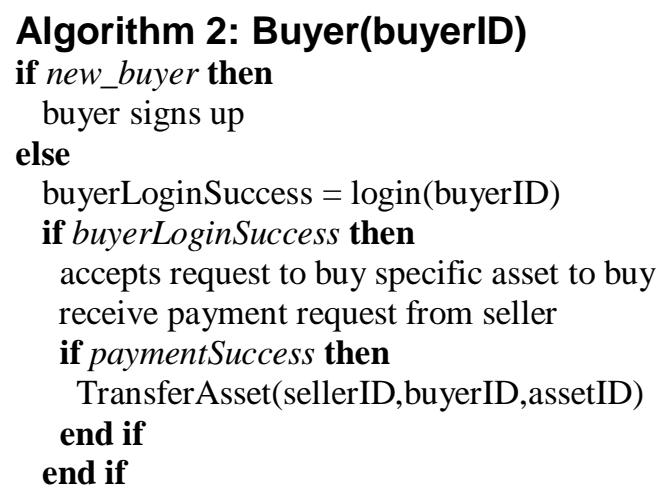




end if end if
end if
end if

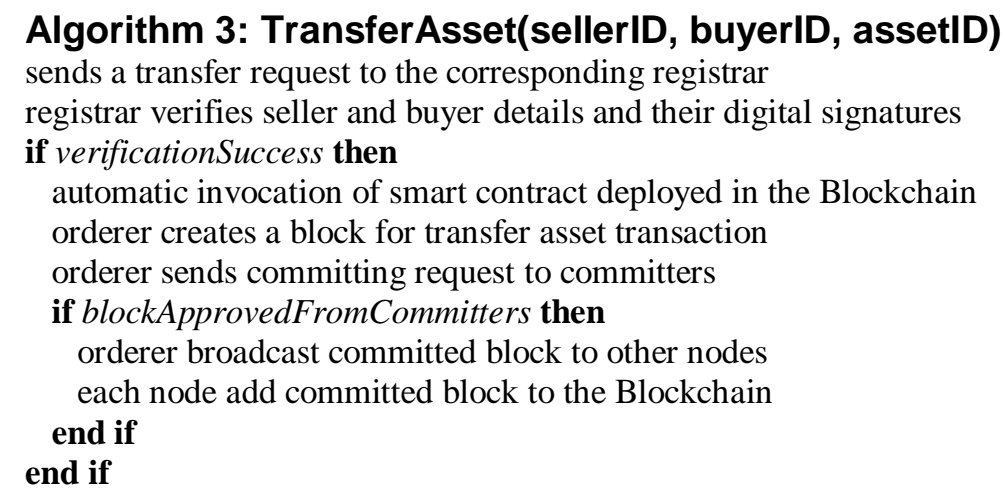

\section{Evaluation and Results}

Implementation is done using Hyperledger Fabric consisting of four peers and used Hyperledger Caliper, blockchain benchmark tool to evaluate the performance of our proposed Blockchain-based land registration system. Hyperledger Caliper enables users to test blockchain solutions with predefined use cases and get performance indicators such as Success rate, throughput, latency (minimum, maximum, average, percentile) and Resource consumption (CPU, Memory, Network IO). Table 4 gives the details of the parameter used for evaluation.

Table 4. Parameters for evaluation in Hyperledger Caliper

\begin{tabular}{|c|c|c|c|}
\hline Transaction Type & \#Transactions & Block Size & Arrival Rates \\
\hline Insert & 1000 & 10 & $30-120$ tps \\
\hline Query & 1000 & 10 & $4-12$ tps \\
\hline
\end{tabular}

\subsection{Evaluation Metrics}

Average latency:- Transaction latency is defined as, time taken by a transaction to get added in Blockchain.

Throughput:- Rate at which the valid transactions committed into the Blockchain.

Execution Time:- Time taken to commit all the transactions in the Blockchain.

\subsection{Results}

Transactions done in the blockchain network is classified under two categories, i) Insert transaction and ii) Query transaction.

In the Hyperledger Caliper tool, transactions are committed to the blockchain network in batch, and there exists an optimal throughput for every blockchain network. If the arrival rate of the transactions lesser than the optimal throughput, each transaction waits less time in the network to get it confirmed, thereby decreasing the latency time. In the same way, if the arrival rate of the transactions higher than the optimal throughput, each transaction stays a long time in the network queue and so increase in latency time. Experiments were conducted on two categories of transactions to understand the impact of arrival rate on optimal throughput of the blockchain network. 
Experiment for insert transaction: For Insert transactions, we kept a number of transactions to 1000 , with a block size of 10 and arrival rate from 30 to 120 transactions per second(tps). Fig. 6 shows the impact of arrival rate on evaluation metrics for insert transaction. We have observed that the latency decreases until the arrival rate of transactions reaches the optimal throughput(70 tps). After that, the latency tends to increase. Moreover, execution time decreases till optimal throughput but increases beyond it.

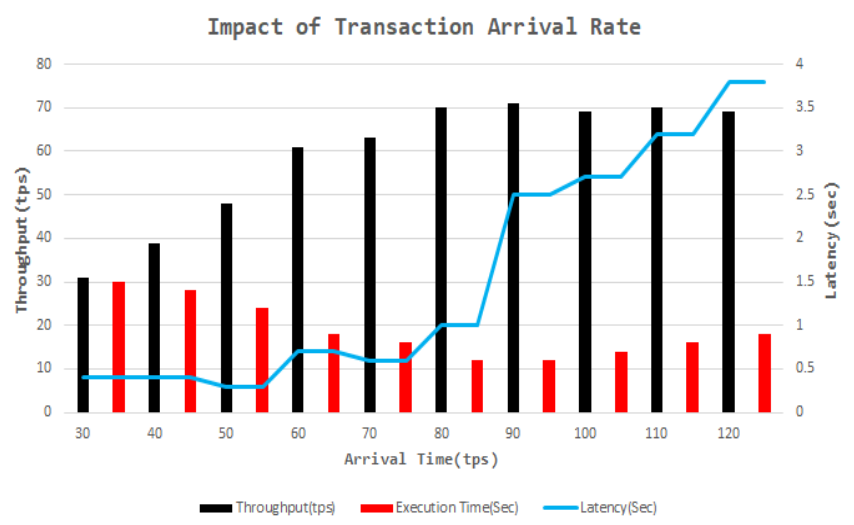

Fig. 6. Impact of arrival rate on evaluation metrics for insert transaction

Experiment for query transaction: In query transactions, each transaction does the search operation in CouchDB and have a higher number of operations when compared to insert transaction. For query transactions, we kept \# no of ledger transactions to 1000, with a block size of 10 and arrival rate from 4 to 12 transactions per sections(tps). Fig. 7 shows the impact of arrival rate on evaluation metrics for insert transaction and observed that the optimal throughput for query transactions is 8 tps. It is shallow when compared to the optimal throughput(70 tps) for insert transactions as the query transaction takes time to search entire ledger.

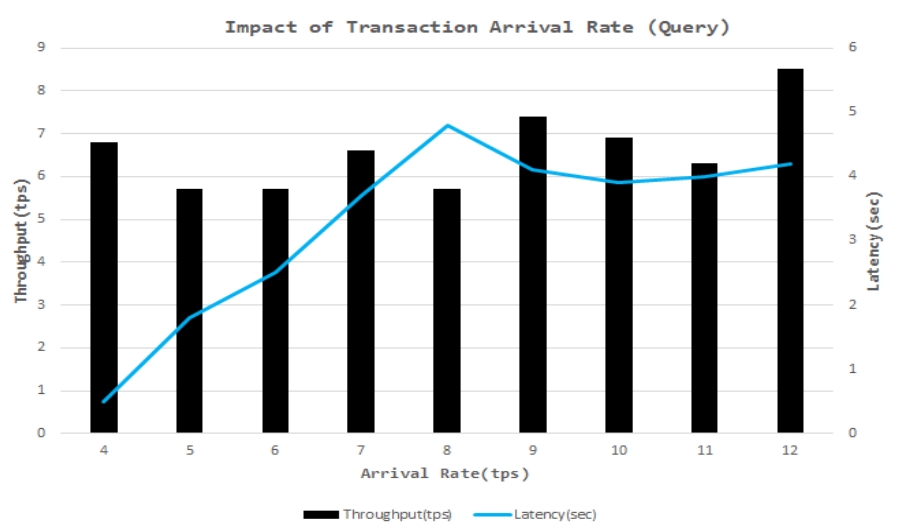

Fig. 7. Impact of arrival rate on evaluation metrics for query transaction 


\section{Findings and Discussion}

The 2011 UN report says that Weak Governance led to corruption in land occupancy and administration in more than 61 countries. Corruption ranges from small scale bribes to the abuse of government power at all levels from national, state to local. The protection of digital resources is also the trouble for both government and citizens. As of now, the government uses a shared server to record data about citizens. The main problem is if the server hacked by an attacker, it will result in leakage of valuable data. In this case, the citizen is not aware of this leakage, so it adds some responsibility to the government to derive a mechanism for protection of citizen's data. The software that the government uses may provide some backdoor for attackers to conduct attack without being discovered. Blockchain technology offers a smart solution to this security issue.

The Blockchain technology has the potential to make up for lack of sufficient formal institutions such as rules, laws, regulations, and their enforcement. The main advantage of using blockchain technology in e-Governance is that it makes of an immutable distributed ledger storage model when compared to traditional databases, and it protects the data from possible frauds. The state government holds responsibility for keeping accurate and valid data about individuals, assets, and activities associated with it in the chain of blocks. The current block is linked with the previous block by hash value and makes the ledger the safest and most convenient medium to store and transfer data. Recording stored information about citizens, assets, etc. as a block in Blockchain ensures that it's almost difficult to modify the same block later. Hence, it is possible to accept data from such distributed ledger as trusted, as long as the data in it is reliable.

The smart contract is another significant benefit of Blockchain technology. Several mechanisms and methods of communication between state and citizens can be achieved by it as the distributed ledger holds only legally valid information. The code in the smart contract does not allow unauthorised modification and secure its execution at any point when specific conditions met. Moreover, the distributed ledger is public; thereby, it guarantees transparency and available for anyone's view. If a malicious user in the blockchain network wants to attack the distributed ledger, other users in the network will deny it. Besides, the Blockchain maintains every activity of the user. If someone tries to mutate a transaction in a block, it results in a change in the Merkle tree, which deviates the current block hash. An important consideration while transiting from the current platform to Blockchain lies in incorporating data about the citizen in the ledger. Utmost care should be taken while granting access rights as blockchain technology provides access control rights to nodes, users and smart contracts in the network.

\subsection{Comparison with a similar system}

Vinay Thakur et al. [43], explored the need for blockchain technology for safekeeping of land records in India. Authors also illustrated their work as a system, build using blockchain technology for implementing tamper-proof and authentic rights of ownership for land titling in India. A detailed discussion and comparison of the work proposed by Vinay Thakur et al. and by us detailed in the forthcoming paragraph, the difference between the two is former uses blockchain technology for land titling, while later uses for land registration. Besides, the paper [43] explains the only theoretical concept and lacks in experimental proofs.

Once the buyer and seller accept for land registration, the smart contract invokes automatically, and the draft sale deed is approved by the registrar to do further steps. The completed transaction appended to the ledger. In contrast, in the system design mentioned by 
the Vinay Thakur et al., the transactions are appended after the consensus achieved with all the nodes. The nodes include buyer, bank, court, tehsil, sub-registrar office, survey. The bank shall use the ledger for the loan verification process but involving in the network for the consensus process makes the system design more complex. Every time, when a new block gets added to the ledger, the consensus mechanism instantiated involving with other nodes available in the network. The significant question that arises here is how could be the nodes that are not involved in the transaction, contributed arriving at a consensus. In our proposed work, two registrars are randomly chosen for approval, whereas in [43], a registrar involves in the verification process. The benefit of using two registrars for verification process reduces the opportunity for fraudulent transactions.

\subsection{Comparison with other Governance platforms}

We took performance aspects such as Transparency, Data Correctness, Corruption, Error Traceability, and Mutability to evaluate the performance of our proposed work with other Governance platforms [44]. Table 5 highlights the findings and compares with different modes of Governance, i.e., i) manual work in Government, ii) e-Governance and iii) e-Governance adopting Blockchain Technology. In today's world, governments main issue is how to eradicate corruption, by using e-Governance with BT, the job is done with some little effort when compared to e-Governance. Error Traceability is easy while adopting e-Governance with BT, and it is difficult in other modes. Findings highlighted in Table 5 shows positive signs while adopting e-Governance with BT.

Table 5. Performance comparison of manual work in Government, e-Governance and e-Governance with BT

\begin{tabular}{|l|c|c|c|}
\hline Performance Aspect & Manual & e-Governance & e-Governance with BT \\
\hline Transparency & Low & Moderate & High \\
\hline Data Correctness & Low & Moderate & High \\
\hline Corruption & Yes & Yes & No \\
\hline Error Traceability & Difficult & To some extent & Easy \\
\hline Mutability & Yes & Yes & No \\
\hline
\end{tabular}

\section{Conclusion}

An emerging technology Blockchain has laid its foundation not only in digital currencies but also in various industries nowadays. This paper aimed to propose a blockchain framework for effective e-Governance in Land registration department to combat corruption and for valuable usage of designated funds in that department. Blockchain technology improves the delivery of public services offered by the government. The distributed ledger employs as an official ledger that records relevant data about the department and their interaction with its citizen. All governance-related data are added in the block with time stamp and once added to the Blockchain; it is immutable. Moreover, it provides a secure communication channel between the government and citizens. The application of blockchain technology in e-Governance gives the safest environment for data storage and processing. It brings transparency of information and does not encourage corrupt practices as every activity on the data is recorded in public distributed ledger. Hence, the auditing of data stored in the Blockchain is a simple and easy task. The other key advantages are notable reduction in bureaucracy, eliminates paperwork, reduces service delivery time and transactional costs, control on officials, thereby fight off 
corruption. Overall, the blockchain technology will increase the trust of citizens in their government.

\section{References}

[1] Valentina Ndou, "E-Government for Developing Countries: Opportunities and Challenges,” The Electronic Journal of Information Systems in Developing Countries, vol. 18, no. 1, pp. 1-24, 2004. Article (CrossRef Link)

[2] Ekendra, "What Is eGovernment? Some Official Definitions of E-Government," EkendraOnLine, January 5, 2014, accessed on July 01, 2019. https://ekendraonline.com/egovernance/egovernment-official-definitions/\#WB.

[3] A. Gupta and R. Bansal, "E-Governance: A Step Ahead," in Proc. of 2013 Third International Conference on Advanced Computing and Communication Technologies (ACCT), Rohtak, pp. 359-362, 2013. Article (CrossRef Link)

[4] P. P. Ray, "Digital India: Perspective, challenges and future direction," in Proc. of 2018 International Conference on Power, Signals, Control and Computation (EPSCICON), Thrissur, pp. 1-8, 2018. Article (CrossRef Link)

[5] R. K. Das, S. Patnaik, A. K. Misro, "Adoption of Cloud Computing in e-Governance," in Proc. of Springer Advanced Computing. CCSIT 2011. Communications in Computer and Information Science, vol. 133, pp 161-172, 2011. Article (CrossRef Link)

[6] S. Ølnes, J. Ubacht, M. Janssen, "Blockchain in Government: Benefits and Implications of Distributed Ledger Technology for Information Sharing," Government Information Quarterly, vol. 34, no. 3, pp. 355-364, 2017. Article (CrossRef Link)

[7] F. O. Jimoh, U. G. Abdullahi, I. A. Ibrahim, "An Overview of Blockchain Technology Adoption," Journal Of Computer Science And Information Technology, vol. 7, no. 2, 2019.

Article (CrossRef Link)

[8] A Report on, "E-Government Development Index," published by United Nations, 2019, accessed on July 05, 2019.

https://publicadministration.un.org/egovkb/en-us/About/Overview/-E-Government-Developme nt-Index

[9] A Report on, "UN E-Government Knowledgebase Country Data," published by United Nations, 2019, accessed on July 08, 2019.

https://publicadministration.un.org/egovkb/en-us/Data-Center

[10] P. Anu, and P. Varghese, "E-Government Development Scenario in India Based on United Nations Surveys," International Journal of Current Research, vol. 7, no. 4, pp.15451-15461, 2015. Article (CrossRef Link)

[11] P. Mittal, and A. Kaur, "E-Governance - a Challenge for India," International Journal of Advanced Research in Computer Engineering and Technology, vol. 2, no. 3, pp.1196-1199, 2013. Article (CrossRef Link)

[12] P. Anu, "E-Governance, a Paradigm Shift in India," International Journal of Interdisciplinary Studies and Research, vol. 11, no. 1, pp.63-73, 2010. Article (CrossRef Link)

[13] W. Reijers, F. O'Brolcháin, and P. Haynes, "Governance in Blockchain Technologies and Social Contract Theories," Ledger, vol. 1, pp.134-151, 2016. Article (CrossRef Link)

[14] M. Swan, Blockchain: Blueprint for a New Economy, OReilly, 2015. ISBN:978-1-4919-2049-7

[15] B. Akins, J. L. Chapman, and J. M. Gordon, "A Whole New World: Income Tax Considerations of the Bitcoin Economy,” SSRN, 2014, accessed on July 15, 2019. https://papers.ssrn.com/sol3/papers.cfm?abstract id=2394738

[16] H. Hou, "The Application of Blockchain Technology in E-Government in China," in Proc. of 26th International Conference on Computer Communication and Networks (ICCCN), pp.1-4, 2017. Article (CrossRef link)

[17] C. Sullivan, and E. Burger, "E-Residency and Blockchain," Computer Law and Security Review, vol. 33, no. 4, pp.470-481, 2017. Article (CrossRef Link) 
[18] K. Biswas, and V. Muthukkumarasamy, “Securing Smart Cities Using Blockchain Technology,” in Proc. of IEEE 18th International Conference on High-Performance Computing and Communications, pp.1392-1393, 2016. Article (CrossRef Link)

[19] P.K. Sharma, S. Y. Moon, and J. H. Park, "Block-Vn: A Distributed Blockchain-Based Vehicular Network Architecture in Smart City,” Journal of Information Processing Systems, vol. 13, no. 1, pp.184-195, 2017. Article (CrossRef Link)

[20] M. Pilkington, C. Rodica, and L. G. Grant, "Blockchain and Bitcoin as a Way to Lift a Country Out of Poverty-Tourism 2.0 and E-Governance in the Republic of Moldova,” International Journal of Internet Technology and Secured Transactions, vol. 7, no. 2, pp.115-143, 2017. Article (CrossRef Link)

[21] M. Jun, "Blockchain Government - a Next Form of Infrastructure for the Twenty-First Century," Journal of Open Innovation: Technology, Market, and Complexity, vol. 4, no. 7, 2018. Article (CrossRef Link)

[22] "Australian Blockchain Sector Welcomes Formation of Parliamentary Friendship Group," Blockchain Australia, 18 July 2019.

https://blockchainaustralia.org/australian-blockchain-sector-welcomes-formation-of-parliament ary-friendship-group/

[23] U. W. Chohan, "Blockchain and Securities Exchanges: Australian Case Study,” Discussion Paper, pp. 1- 6, 2017. Article (CrossRef Link)

[24] N. Kshetri, "Will blockchain emerge as a tool to break the poverty chain in the Global South?," Routledge Taylor \& Francis Group, Third World Quarterly, vol. 38, no. 8, pp. 1710-1732, 2017. Article (CrossRef Link)

[25] J. Veuger, "Attention to Disruption and Blockchain Creates a Viable Real Estate Economy," Journal of US-China Public Administration, vol. 14, no. 5, pp. 263- 285, 2017. Article (CrossRef Link)

[26] S. Ibba, A. Pinna, and et al., "CitySense: blockchain-oriented smart cities," in Proc. of ACM XP '17: Proceedings of the XP2017 Scientific Workshops, Article No. 12, pp. 1-5, 2017.

Article (CrossRef Link)

[27] Smart Dubai, "Dubai Blockchain Strategy,” 2016. https://www.smartdubai.ae/initiatives/blockchain

[28] G. Anthes, "Estonia: a model for e-government," Communications of the ACM, vol. 58, no. 6, pp. 18 - 20, 2015. Article (CrossRef Link)

[29] M. Mettler, "Blockchain Technology in Healthcare: The Revolution Starts Here.," in Proc. of IEEE 18th International Conference on e-Health Networking, Applications and Services (Healthcom), 2016. Article (CrossRef Link)

[30] F. Hartleb, “E-Estonia - "Europe’s Silicon Valley” or a New “1984”?,” Redesigning Organisations, Concepts for the Connected Society, Springer, pp. 215 - 228, 2019. Article (CrossRef Link)

[31] D. Sachdev, D. Chakrabarti, and A. Mitta, "Review of Ownership Based Blockchain Frameworks in Government Applications,” IITM Journal of Business Studies (JBS), vol. 6 no. 1, pp. 22-32, 2019. Article (CrossRef Link)

[32] S. Sundararajan, "France Approves Blockchain Trading of Unlisted Securities using blockchain technology, Reuters reports,” 2017. https://www.coindesk.com/france-gives-go-ahead-for-blockchain-trading-of-unlisted-securities

[33] O. Ogundeji, "Land Registry Based on Blockchain for Africa," IT Web Africa, blog, 2016, https://itweb.africa/content/raYAyModrd4qJ38N

[34] S. Higgins, "Republic of Georgia to Develop Blockchain Land Registry,” Coindesk, blog, 2016; https://www.coindesk.com/bitfury-working-with-georgian-government-on-blockchain-land-reg istry

[35] G. Eder, "Digital Transformation: Blockchain and Land Titles,” in Proc. of OECD Global Anti-Corruption and Integrity Forum, 2019. Article (CrossRef Link) 
[36] T. Ashimbayev and S. Tashenova, "Prospects for Using Cryptocurrency in the Economy of Kazakhstan and the Attitude of the National Bank,” European Research Studies Journal, vol. 21, no. 4, pp. 524-532, 2018. Article (CrossRef Link)

[37] K. A. Koshechkin, G.S.Klimenko and et. al., "Scope for the Application of Blockchain in the Public Healthcare of the Russian Federation," Procedia Computer Science, vol. 126, pp. 1323-1328, 2018. Article (CrossRef Link)

[38] L. Karry, "Singapore banks using DLT to tackle money laundering," International Financial Law Review, 2018. https://search.proquest.com/openview/4072f370a5c029467c14e29b9139af4d/1?pq-origsite=gs cholar\&cbl=36341

[39] J. McMurren, A. Young, and S. Verhulst, “Addressing Transaction Costs Through Blockchain and Identity in Swedish Land Transfers,” Blockchain Technologies for Social Change, GovLab, 2018. Article (CrossRef Link)

[40] M. Koopman, "Blockchain in Switzerland,” Kingdom of Netherlands, 2018. Article (CrossRef Link)

[41] S. Das, "UK Trials Blockchain-Based Social Welfare Payments,” CCN.com, Published July 7, 2016, https://www.ccn.com/uk-trials-blockchain-based-social-welfare-payments/

[42] D. V. Dimitrov, “Blockchain Applications for Healthcare Data Management,” Healthc Inform Res., vol. 25, no.1, pp. 51-56, 2019. Article (CrossRef Link)

[43] V. Thakur, M., Dojab, Y. K. Dwivedi, T. Ahmadd, and G. Khadanga, "Land Records on Blockchain for Implementation of Land Titling in India," International Journal of Information Management, vol. 52, 2019. Article (CrossRef Link)

[44] P. Suri, and Sushil, "Measuring E-Governance Performance," Published in Springer Science, Performance Strategic Planning and Implementation of E-Governance, pp. 25-39, 2016. Article (CrossRef Link)

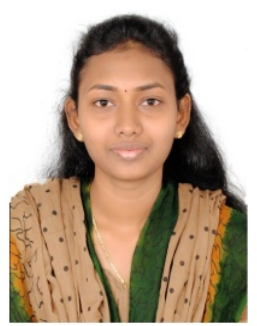

Karthika Veeramani, Research Scholar in the Department of Computer Science and Engineering, Sri Sivasubramaniya Nadar College of Engineering. She did her M.E Computer Science and Engineering from Anna University and B.Tech Information Technology from University College Of Engineering, Bitcampus Tiruchirappalli. To her credits, she published a paper in reputed International conference and journals. She had two years of Industrial Experience worked as a Programmer Analyst in Cognizant Technology Solutions, Chennai. Apart from this, she filed a patent on Regularized Discriminant Analysis. Her areas of interest are Big Data Analytics, Machine learning, Blockchain Technology.

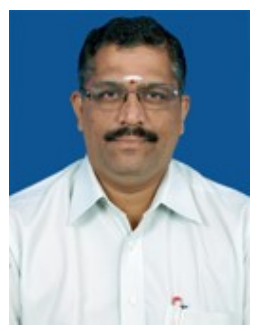

Suresh Jaganathan, Associate Professor in the Department of Computer Science and Engineering, Sri Sivasubramaniya Nadar College of Engineering, has more than 22 years of teaching experience. He received his $\mathrm{PhD}$ in Computer Science from Jawaharlal Nehru Technological University, Hyderabad, M.E Software Engineering from Anna University and B.E Computer Science \& Engineering, from Madurai Kamarajar University, Madurai. He has more than 30 publications in refereed International Journals and Conferences. Apart from this, to his credit, he has filed two patents and written a book on "Cloud Computing: A Practical Approach for Learning and Implementation," published by Pearson Publications. He is an active reviewer in reputed journals (Elsevier - Journal of Networks and Computer Applications, Computer in Biology and Medicine) and also co-investigator for the SSN-NIVIDA GPU Education centre. His areas of interest are Distributed Computing, Deep Learning, Data Analytics, Machine learning \& Blockchain Technology. 